\title{
Phytotoxic Melampolides from Leaf Extracts of Samallanthus sonchifolius*
}

\author{
Shigeru Tamogami**, Yumiko Nakazato** and Osamu Kodama**
}

Key words: Yacon (Smallanthus sonchifolius), phytotoxic, enhydrin

キーワード : ヤーコン，植物成長阻害活性，エンヒ ドリン

\section{Introduction}

Yacon [Smallanthus sonchifolius (Poepp. and Endl.) H. Robinson; Compositae], originally cultivated in the Andean highlands, was introduced in Japan via New Zealand in 1985. In the Andean region, the tubers are served as food and the aerial parts are utilized as fodder for animals ${ }^{7}$. Yacon has recently become very famous because of the high concentration of oligofructans ${ }^{11}$ in its tubers. We have been interested in yacon in another respect because it is easily cultivated without pesticides.

We earlier isolated antifungal compounds including a novel antifungal melampolide, sonchifolin $^{3)}$ from yacon leaves. We speculated that the plant may contain other bioactive compounds as agrochemicals because Compositae is well known to be rich in useful bioactive compounds. Here, we report the isolation and properties of

* A part of this study was presented at the 35 th annual meeting of the Weed Science Society of Japan.

** Lavoratory of Bio-organic and Pesticide chemistry, school of Agricultural, Ibaraki University. 3-21-1 Chuo, Ami, Ibaraki 300-03, Japan 田母神繁***. 中里由美子***・児玉 治*** コン (Samallanthus sonchifolius) 葉抽出物に含ま れる植物成長阻害活性を示すメランポリド

*** 茨城大学農学部資源生物科学科

(Received May 7, 1996) phytotoxic compounds from yacon leaves.

\section{Materials and Methods}

\section{Plant material}

Yacon (S. sonchifolius) was cultivated at the Experimental Farm of Ibaraki University in Ami.

\section{Bioassay}

Samples in methanol were put on filter paper $(5.5 \mathrm{~cm}$, diameter $)$ in a petri dish. After methanol had evaporated, $3 \mathrm{ml}$ of distilled water was added. Four germinated seeds of lettuce (Lactuca sativa. L.) and barnyardgrass (Echinochloa oryzicola Vasing.) were placed on the filter paper and kept at $25^{\circ} \mathrm{C}$ under fluorescent light. After 7 days, the radicle length of the lettuce and barnyardgrass was measured and the inhibition percentage was calculated against control. The experiment was repeated twice.

\section{Isolation of the active compound}

Crude extract was obtained from $800 \mathrm{~g}$ of fresh yacon leaves as described ${ }^{3)}$ and the crude extract was loaded on a silica gel column (eluted with EtOAc: Hex $=2: 1$ ) to afford the active fractions. The active fractions were concentrated and dissolved in a small volume of $\mathrm{MeOH}$ and kept at $5{ }^{\circ} \mathrm{C}$ for 2 days to give crystals of the active compound (40 mg), which appeared as one peak by HPLC analysis (Cosmosil 5C18AR, $\mathrm{CH}_{3} \mathrm{CN}$ : $\left.\mathrm{H}_{2} \mathrm{O}=1: 1\right)$ detected at $210 \mathrm{~nm}$.

\section{Hydrogenation of enhydrin}

A solution of enhydrin ( $5 \mathrm{mg})$ and $5 \% \mathrm{Pd} / \mathrm{C}$ $(5 \mathrm{mg})$ in ethanol $(2 \mathrm{ml})$ was stirred overnight 
under $\mathrm{H}_{2}$ at room temp. After removal of $\mathrm{Pd} / \mathrm{C}$ by filtration, solvent was removed to give hydrogenated enhydring quantitatively.

\section{Results and Discussion}

We purified the active compound by following the activity against lettuce. Properties of the active compound were as follows: IR (v max, neat) $\mathrm{cm}^{-1}: 1771,1715,1230,1120$. FD-MS m/z $465(\mathrm{M}+\mathrm{H}), 349,99,88 .{ }^{1} \mathrm{H}^{-}$ NMR $\left(500 \mathrm{MHz} \mathrm{CDCl}_{3}\right) ; \delta 1.17(3 \mathrm{H}, \mathrm{d}, \mathrm{J}=5.5$ $\mathrm{Hz}), \quad 1.45(3 \mathrm{H}, \mathrm{s}), 1.71(3 \mathrm{H}, \mathrm{s}), 2.05(3 \mathrm{H}, \mathrm{s})$, 2.35(1H, m), 2.46 $(1 \mathrm{H}, \mathrm{m}), 2.67(1 \mathrm{H}, \mathrm{d}, \mathrm{J}=10.0$ $\mathrm{Hz}), 3.00(3 \mathrm{H}, \mathrm{m}), 3.83(3 \mathrm{H}, \mathrm{s}), 4.28(1 \mathrm{H}, \mathrm{t}, \mathrm{J}=$ $10.0 \mathrm{~Hz}), 5.84(1 \mathrm{H}, \mathrm{d}, \mathrm{J}=3.3 \mathrm{~Hz}), 5.87(1 \mathrm{H}, \mathrm{d}, \mathrm{J}=$ $9.1 \mathrm{~Hz}), 6.34(1 \mathrm{H}, \mathrm{d}, \mathrm{J}=3.5 \mathrm{~Hz}), 6.71(1 \mathrm{H}, \mathrm{dd}, \mathrm{J}=$ 9.1, $1.3 \mathrm{~Hz}), \quad 7.15(1 \mathrm{H}, \mathrm{dd}, \mathrm{J}=10.8,7.5 \mathrm{~Hz})$. ${ }^{13} \mathrm{C}-\mathrm{NMR}\left(125 \mathrm{MHz}, \mathrm{CDCl}_{3}\right) ; \delta 13.6,17.4,19.1$, 20.2, 24.7, 39.4, 45.5, 51.8, 58.9, 59.1, 59.5, 62.7, 70.7, 71.3, 75.8, 121.7, 130.3, 134.4, 147.4, 165.5, $167.9,168.5,170.2$.

These ${ }^{1} \mathrm{H}$ and ${ }^{13} \mathrm{C}-\mathrm{NMR}$, MS, and IR spectra revealed that the active compound was enhydrin $\mathbf{1}^{4}$. Enhydrin 1 inhibited radicle elongation of lettuce seedling $50 \%$ at 100 ppm.

Sonchifolin $3^{3)}$, polymatin $\mathrm{B} 4^{8)}$, uvedalin $5^{2)}$ and enhydrin $\mathbf{1}$ have already been isolated from yacon leaves as fungicidal compounds.
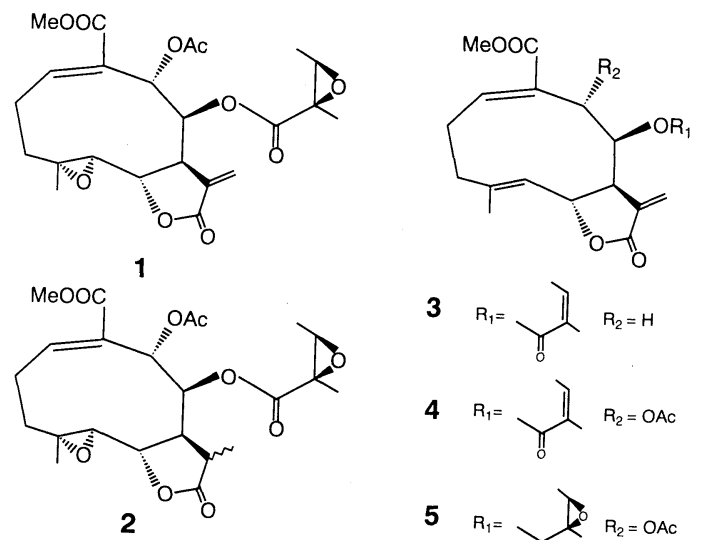

3

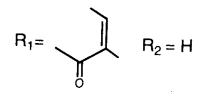

4

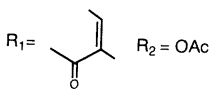

5

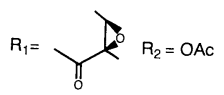

Among these melampolides, sonchifolin 3 showed the most effective fungicidal activity against Pyricularia oryzae followed by polymatin B4, uvedalin 5 and enhydrin 1 in this order ${ }^{3}$.

We compared the phytotoxic activities among these melampolides and found that enhydrin 1 was most effective against lettuce and uvedarin $\mathbf{5}$ was most effective against barnyardgrass. Enhydrin $\mathbf{1}$ was more active against lettuce than against barnyardgrass, while sonchifolin 3, polymatin B4 and uvedalin $\mathbf{5}$ were more active against barnyardgrass. These results are summarized in the Table 1. Negligible activity was shown against the aerial part of these plants. To our best knowledge, this is the first report on the phytotoxic activities of these melampolides including enhydrin $\mathbf{1}$.

We modified this $\alpha$-methylene- $\gamma$-lactone moiety of enhydrin 1 by hydrogenation with $\mathrm{Pd} / \mathrm{C}$ to prepare derivative 2 , because this moiety is present in many of the isolated natural melampolides, and has been proposed as one of the factors which can serve their allelophathic activities ${ }^{6}$. In ${ }^{1} \mathrm{H}-\mathrm{NMR}$ spectrum of derivative 2 , new signals came up at $\delta 1.27(3 \mathrm{H}, \mathrm{d}, \mathrm{J}=5.5 \mathrm{~Hz})$ and $\delta 2.98(1 \mathrm{H}, \mathrm{m})$ instead of two olefinic protons at $\delta 6.71$ and $\delta 5.87 \mathrm{ppm}$, suggesting that hydrogenation

Table 1. Phytotoxic Activities of Enhydrin (Compound 1) and its Related Compounds 2-5.

\begin{tabular}{ccccc}
\hline \multicolumn{3}{c}{ Inhibitory activity (\%) against } & radicle growth* \\
\hline & \multicolumn{2}{c}{ Lettuce } & \multicolumn{2}{c}{ Barnyardgrass } \\
\cline { 2 - 5 } Compound & $100 \mathrm{ppm}$ & $200 \mathrm{ppm}$ & $100 \mathrm{ppm}$ & $200 \mathrm{ppm}$ \\
\hline 1 & 50 & 77 & $-^{* *}$ & 72 \\
2 & $-{ }^{* *}$ & $-{ }^{* *}$ & $-^{* *}$ & $-^{* *}$ \\
3 & $-{ }^{* *}$ & 5 & 77 & 86 \\
4 & 26 & 47 & 73 & 81 \\
5 & $-{ }^{* *}$ & 23 & 95 & 91 \\
\hline
\end{tabular}

${ }^{*}$ Average of eight seeds against control.

${ }^{* *}$ No inhibition. 
took place at this moiety. ${ }^{1} \mathrm{H}-\mathrm{NMR}$ of derivative 2 was as follows: $\left(500 \mathrm{MHz}, \mathrm{CDCl}_{3}\right) \delta$; $1.16(3 \mathrm{H}, \mathrm{d}, \mathrm{J}=7.5 \mathrm{~Hz}), 1.27(3 \mathrm{H}, \mathrm{d}, \mathrm{J}=5.5 \mathrm{~Hz})$, 1.48(3H, s), 1.68(3H, s), $2.00(3 \mathrm{H}, \mathrm{s}), 2.32(1 \mathrm{H}$, $\mathrm{m}), 2.42(1 \mathrm{H}, \mathrm{m}), 2.55(2 \mathrm{H}, \mathrm{m}), 2.28(1 \mathrm{H}, \mathrm{m})$, $2.98(1 \mathrm{H}, \mathrm{m}), 3.05(1 \mathrm{H}, \mathrm{m}), 3.80(3 \mathrm{H}, \mathrm{s}), 4.48(1 \mathrm{H}$, $\mathrm{t}, \mathrm{J}=10.5 \mathrm{~Hz}), 5.80(1 \mathrm{H}, \mathrm{d}, \mathrm{J}=7.5 \mathrm{~Hz}), 6.30(1 \mathrm{H}$, $\mathrm{d}, \mathrm{J}=7.5 \mathrm{~Hz}), 7.08(1 \mathrm{H}, \mathrm{dd}, \mathrm{J}=11.5,6.5 \mathrm{~Hz})$. Derivative 2 showed no inhibitory activity against either lettuce or barnyardgrass at 200 ppm. Thus, this $\alpha$-methylene- $\boldsymbol{\gamma}$-lactone moiety in enhydrin 4 was suggested to be important for the phytotoxic activity.

Recently Macias ${ }^{5)}$ reported that melampolide is one of the most potential natural allelochemicals from higher plants. Yacon is a very useful plant which contains these potential natural agrochemicals.

Acknowledgement: We thank Professor T. Tsukihashi, Ibaraki University for providing the plant material.

\section{References}

1) Oyama, T., O. Ito, S. Yasuyoshi, T. Ikarashi, K. Minamisawa, M. Kubota, T. Tsukihashi and T. Asami 1990. Composition of storage carbohydrate in tubers of yacon (Smallanthus sonchifolius). Soil Sci. Plant Nutr 36(3), 167-
169.

2) Herz W. and S.V. Bhat 1970. Isolation and structure of two new Germacranolides from Polymnia uvedaria (L.) L.J. Org. Chem. 35(8), 2605-2609.

3) Inoue, A., S. Tamogami, H. Kato, Y. Nakazato, M. Akiyama, O. Kodama, T. Akatsuka and Y.Hasidoko 1995. Antifungal melampolides from leaf extracts of Samallanthus sonchifolius. Phytochemistry 39(4), 845-848.

4) Joshi B.S., V.N. Kamato and H. Fuher 1971. Revised structure of enhydrin. Tetrahedron Lett., (26), 2373-2376.

5) Macias F.A. 1995. In "Allelopathy" ed. by Inderjit, K.M.M. Dakshini, F.A. Einhellig, American Chemical Society, Washington, DC, pp. 310-329.

6) Macias F.A., J.C.G. Galindo and G.M. Massanet 1992. Potential allelopathic activity of several sesquiterpene lactone models. Phytochemistry 31(6), 1969-1977.

7) Tsukihashi, T., T. Yoshida, M. Miyamoto and N. Suzuki 1989. Studies on the cultivation of yacon I. Influence of different planting on the tuber yield. Japanese Journal of Farm Work Research 24(1), 32-38. (in Japanese with English summary)

8) Van N.L. and N.H. Fisher 1979. Three new melamplide sesquiterpenes, polymatin A, B and C, from Polymnia maculata Cav. var. Maculata. Phytochemistry 18, 851-853. 